\title{
Heinrich Henckel
}

Conventional wisdom is that biotech floatations in Europe belong on the London stock market. But the CEO of the Swiss stock exchange is bullish about the advantages of his exchange for life science ventures.

A lawyer by training, Heinrich Henckel has been schooled in the art of building a strong argument to support his case. Now in his position as CEO of the SWX Swiss Exchange, he asserts that the exchange has everything that a biotech company could wish for when looking to list in Europe. Even so, he will need all his powers of persuasion if he is to attract biotech companies from outside his home country-as yet, not a single foreign biotech firm has managed to list on the SWX Swiss Exchange in the most recent initial public offering (IPO) window.

Henckel, who has been the head of the exchange since 2000, is convinced that the SWX Swiss Exchange can be just as attractive as the London Stock Exchange (LSE). Not only is Switzerland home to several large cap biotech companies, like Serono (Geneva), Actelion (Basel), Berna Biotech (Berne) and Basilea (Basel), he says, but it is also host to the headquarters of several large pharmaceutical companies. What's more, Switzerland boasts sophisticated institutional investors and a set of financial institutions that manage a quarter of the world's cross-border assets.

Many investment bankers do recognize the value of listing on the SWX Swiss Exchange, but regard the LSE as just as attractive. Because biotech companies generally have market capitalizations of less than a billion dollars, LSE and SWX Swiss Exchange provide biotech stocks with greater visibility; in contrast, US exchanges like NASDAQ are dominated by large-cap companies. The requirement of US markets for company compliance with Sarbanes-Oxley financial disclosure regulations - estimated to cost between $\$ 700,000$ and $\$ 1$ billion annually_also makes European exchanges (which are largely self-regulating) more welcoming to small cap biotechs.

Despite these potential advantages, the LSE, whose sub-segment the Alternative Investment Market (AiM) is specifically geared to low capitalization companies, has not exactly been a roaring success in attracting foreign life science companies. Only four biotech companies have a primary listing on AiM (two from Canada, one from the United States and another from Australia), compared with three on SWX Swiss Exchange (one US and two Israeli companies).

Henckel believes that this situation is changing. Already, he has streamlined exchange regulations/structure to be more attractive to small-cap biotech companies. Besides simplifying listing rules, "we have gone further by creating life science indices to provide visibility to those companies," Henckel adds. These are the SXI Life Science index (which covers pharma, medtech and biotech) and the more specific SXI Bio+Medtech sub-index. He also actively grooms companies "years before they are ready to go to the market" in the hope that they will ultimately choose SWX Swiss Exchange when they go public.

For example, Swiss antiinfective biotech Arpida, headquartered in Münchenstein, was able to list on SWX Swiss Exchange on May 4, completing all the paper work within 4 weeks. The company, which took its injectable antibiotic iclaprim (a diaminopyrimidine) into phase 3 trials a few months before listing, already had 55 investors and managed to raise CHF18 (\$14) million in October 2004, resulting in a good valuation. But not all the news is rosy. On May 11, for example, targeted therapeutic company Speedel of Basel (with a phase 3 product and significant pipeline) withdrew plans to list on SWX Swiss Exchange quoting "market conditions."
According to Arpida's CEO Khalid Islam, the problem is that there are not enough biotech specific investors in Switzerland. Those who are actually investing in biotech are Swiss institutional investors who have been in the life science sector because of the presence of big pharma in the country. London, in contrast, has a much larger concentration of sector-specific investors: "They are the important players," Islam says.

Doug McCutcheon, managing director in UBS Investment Bank's Global Healthcare Team, counters that London-based sector specific investors do have a mandate to invest broadly across Europe. He attributes the lack of cross border listing to the low number of IPOs. What's more, investment bankers tend to advise their clients to invest on 'the most natural market' for them; typically their home turf. Thus, Galashiels, UK-based ProStrakan, a company that specializes in bone diseases, women's health and aging, chose to list on the LSE on June 16; Belgian therapeutic and agbiotech firm DevGen listed on the Brussels-based Euronext on June 7; and Danish oncology biotech TopoTarget listed on the Copenhagen Stock Exchange on June 10.

McCutcheon explains that companies need a "good reason"-such as the presence of partners or investors abroad-to list outside their home market, where the so-called local hero effect is an important factor in IPO success. But for those companies based in countries where local exchanges do not have sufficient liquidity (e.g., Austria, France, Germany,

It will take a long time
for [exchange] platforms
to be brought together
in Europe...the number
of stock exchanges
has increased, not
decreased.

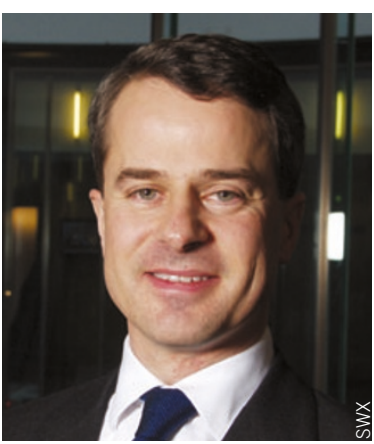

Israel, Italy and Spain), he believes the best bet may be to list either on SWX Swiss Exchange or LSE. For example, when stroke therapeutics firm Paion of Aachen, Germany, listed on the Deutsche Börse in Frankfurt on February 11, it struggled to reach the expected investor uptake in its home territory; in this case, it might have been better to choose SWX Swiss Exchange or LSE.

All in all, European listing largely remains parochial and the long anticipated pan-European exchange for biotech and other small caps remains a distant prospect. Henckel believes "It will take a long time for [exchange] platforms to be brought together in Europe...the number of stock exchanges has increased, not decreased." As a solution and as a counter to the effect of fragmenting exchanges, SWX Swiss Exchange has introduced a system called Vertex, which gives access to equity trading on its exchange from financial centers, such as London and Paris. That boosts SWX Swiss Exchange liquidity and provides a higher level of trading volume, he adds.

Henckel remains upbeat about SWX Swiss Exchange's ability to attract biotech listings: "We have been approached by a number of companies that are not based in Switzerland but interested in listing there." In the present financial climate, he might have to wait some time yet.

Sabine Louët, Dublin. 